\title{
The Tokyo Trial and the Question of Colonial Responsibility: Zainichi Korean Reactions to Allied Justice in Occupied Japan*
}

Young-hwan Chong**

\section{Introduction}

Along with the Nuremberg Trial adjudicating Nazi German crimes, the International Military Tribunal for the Far East (IMTFE, hereafter Tokyo Trial) marked a significant historical event that shaped our understanding of World War II. The Tokyo Trial defined Japan's Manchurian Incident of 1931 and subsequent imperial expansion as "wars of aggression." Some in Japan reject this view. Those who deny Japan's "war responsibility" (sensō sekinin) reject the characterization of an "aggressive war" by labelling it as the so-called "Tokyo Trial view of history." They also criticize the Tokyo Trial as "victor's justice." However, such critiques of the Tokyo Trial and the "Tokyo Trial view of history" neglect a different problem underlying the history of the Tokyo Trial. During the tribunal, the question of Japanese colonial rule was barely discussed in the pursuit of Japan's responsibility for aggression. In other words, the Tokyo Trial

\footnotetext{
* This article is a revised and translated version of an article originally published in Japanese: Young-hwan Chong, "Kaihō chokugo no zainichi Chōsenjin undō to 'sensō sekinin'ron, 1945-1949,' Nihon shokuminchi kenkyū 28 (June 2016): 21-41. I would like to thank Sherzod Muminov and Deokhyo Choi for translation. ** Associate Professor, Center of Liberal Arts, Meiji Gakuin University
} 
failed to address Japan's "colonial responsibility.",

Japanese scholarship on the Tokyo Trial has developed since the 1970s, and scholars have pointed out two major factors explaining the absence of colonial questions in the Tokyo Trial. First, the tribunal did not prosecute "crimes against humanity"; second, the Allied Powers themselves were not critical of their own imperialist past and thus were indifferent to colonial questions in general. ${ }^{2}$ In fact, recent studies have demonstrated the fact that certain documentary proof referring to "comfort women" issues, which in fact indicated their forced experiences as military sexual slaves, had been submitted to and partially acknowledged by the court. Recent studies have also shed new light on the fact that Class-A war criminals sentenced to death were also charged with the responsibility for numerous conventional war crimes (Class-B) committed by their subordinate soldiers. $^{3}$

1 On the notion of "colonial responsibility," see Yōko Nagahara, "What Is a Theory of “Colonial Responsibility”?’(“植民地責任”論とは何か), in Theory of “Colonial Responsibility': A Comparative History of Decolonization (“植民地責任”論: 脱植民 地化の比較史) (Tokyo: Aoki Shoten, 2009); Ryūta Itagaki, "For the Theorization of Responsibility for Colonial Rule,’(植民地支配責任を定立するために) in Unending Colonialism: Gender, Ethnicity/Nation, Race, Class (継続する植民地主義: ジェン ダー/民族/人種/階級) (Tokyo: Seikyūsha, 2005).

2 Shin'ichi Arai, “On War Responsibility,”(戦争責任について) in Studies on Contemporary History and the Textbook Trial (現代歴史学と教科書裁判) (Tokyo: Aoki Shoten, 1973); Shin'ichi Arai, Asia in Contemporary History: Imperialism and Japan's War Responsibility (現代史におけるアジア: 帝国主義と日本の戦争責任) (Tokyo: Aoki Shoten, 1977). Also see Chihiro Hosoya, Nisuke Andō, Yasuaki Ōnuma eds., International Symposium: Rethinking the Tokyo Trial (国際シンポジウム: 東 京裁判を問う) (Tokyo: Kōdansha, 1989); Naokichi Ubukata, “Issues on the Tokyo Trial: “Crimes against Humanities and the Statute of Limitations,”(東京裁判をめぐ る諸論点: ‘人道に対する罪’ と時効) Shisō 719 (May 1984); Kentarō Awaya, “Shadows of the Tokyo Trial,”(東京裁判の影) in On the Tokyo Trial (東京裁判論) (Tokyo: Ōtsuki Shoten, 1989).

3 Hirofumi Hayashi, Class-B and C War Crimes Trials (BC 級戦犯裁判) (Tokyo: Iwanami Shoten, 2005); Hirofumi Hayashi, “'Comfort Women' Issues and War 
Existing studies on the Tokyo Trial have assumed that during the tribunal few in Japan raised the question of Japanese colonialism. Scholars who have examined Japanese attitudes toward the Tokyo Trial argue that there was hardly any discussion on Japanese colonial rule in Korea. ${ }^{4}$ One rare example, characterized by Japanese historian Yoshida Yutaka as "a rather exceptional discussion that touched on the issue of Japan's colonial responsibility," was a reference made by Yomiuri Shimbun editorial writer Chō Fumitsura. According to Yoshida, Chō critically pointed out that the peoples of Korea and Taiwan were "not given any role and chance to testify about Japan's war responsibility.",

Although the existing studies have correctly pointed out the fact that there was little discussion among the Japanese regarding their colonial responsibility, these studies have not examined how Koreans in Japan (zainichi Koreans) responded to the Tokyo Trial. As I discuss in this arti-

Crimes Trials,’(“慰安婦’問題と戦犯裁判) Gendai Shisō 35-10 (August 2007); Yūma Totani, "The Persecution of War Criminals and Judgement in the Tokyo Trial,’(東京裁判における戦争犯罪訴追と判決) in Studies on Contemporary History and the Nanjing Incident (現代歴史学と南京事件) (Tokyo: Kashiwa Shobō, 2006); Yuma Totani, The Tokyo War Crimes Trial: The Pursuit of Justice in the Wake of World War II (Cambridge, Mass.: Harvard University Asia Center, 2008).

4 Shirō Akazawa, "The Formation of the Symbolic Emperor System and War Responsibility Debates,”(象徵天皇制の形成と戦争責任論) Rekishi Hyōron 315 (July 1976); Takashi Ara, "A Trajectory of the Debates over the Tokyo Trial and War Responsibility," (東京裁判 - 戦争責任論の潮流) in An Introductory Study on the History of the Occupation of Japan (日本占領史研究序説) (Tokyo: Kashiwa Shobō, 1994); Yutaka Yoshida, "Debates over War Responsibility during the Occupation Period,”(占領期における戦争責任論) in Studies on Contemporary History and War Responsibility (現代歴史学と戦争責任) (Tokyo: Aoki Shoten, 1997); Yoshiaki Yoshimi, "Japanese Popular Consciousness during the Occupation Period: Debates over War Responsibility,”(占領期日本の民衆意識: 戦争責任論をめぐって) Shiso 811 (January 1992); Yoshiaki Yoshimi, Democracy from the Ashes: Grassroots Experience of the Occupation (焼跡からのデモクラシー: 草の根の占領体験) (Tokyo: Iwanami Shoten, 2014).

5 Yoshida, “Debates over War Responsibility in Occupied Japan,” 196. 
cle, zainichi Korean groups were deeply engaged with the pursuit of Japan's "war responsibility." Their discussions on the Tokyo Trial often presented a critical insight from the perspective of anti-colonialism, and some correctly questioned the absence of colonial responsibility in the pursuit of justice and war responsibility in the Tokyo Trial. In other words, the problems of the Tokyo Trial that scholars started to "discover" in the 1970s had already been discussed by some zainichi Koreans in the late 1940s. In fact, the above mentioned Chō Fumitsura's "exceptional" reference to Japan's colonial responsibility at the time of the tribunal might have come from his close relationship with Korean communities in Japan. When Chō ran for the Setagaya Ward Assembly in Tokyo in 1947, the zainichi Korean organization called the "Committee for Protecting the Rights for Korean Livelihood" rallied support for him. ${ }^{6}$

In this article, I examine the series of discussions made by zainichi Korean groups and media regarding the Tokyo Trial. ${ }^{7}$ For historical sources, I analyze various newspapers and magazines published by zainichi Koreans at that time. In addition to materials collected by zainichi Korean historian Pak Kyŏngsik, I also use zainichi Korean newspapers and magazines held in the Gordon W. Prange Collection at the University of Maryland. ${ }^{8}$ These media sources, just like all other printed materials published during the initial years of the Allied Occupation, were subject to the Oc-

6 Chōsenjin Seikatsu Yōgo Iinkai Nyūsu, April 20, 1947.

7 For bibliographical information on the major zainichi Korean media I use in this paper, see Table 1.

8 On zainichi Korean newspapers and magazines held in the Gordon W. Prange Collection, see Masaaki Miyamoto, "Studies on Korean Movements in Japan after World War II and the Prange Collection,"(解放後在日朝鮮人史研究とプランゲ文庫 - 覚書) in Media Publication and Culture during the Occupation Period (占領期の 言論・出版と文化:〈プランゲ文庫〉展・シンボジウムの記録) (Waseda University and Ritsumeikan University, 2000); Sōmei Kobayashi, Zainichi Korean Mediasphere: Newspaper Publication and Its Dynamics during the Occupation Period (在 日朝鮮人のメディア空間—G H Q 占領期における新聞発行とそのダイナミズム) (Tokyo: Fūkyōsha, 2007). 
Table 1. Media Outlets published by zainichi Korean groups

\begin{tabular}{|c|c|c|c|c|c|c|c|}
\hline Title & Publisher & $\begin{array}{c}\text { Launch } \\
\text { Date }\end{array}$ & $\begin{array}{c}\text { Place of } \\
\text { Issue }\end{array}$ & $\begin{array}{l}\text { Circula- } \\
\text { tion }\end{array}$ & $\begin{array}{c}\text { Frequen- } \\
\text { cy }\end{array}$ & $\begin{array}{l}\text { Lan- } \\
\text { guage }\end{array}$ & Notes \\
\hline $\begin{array}{c}\text { Chōren } \\
\text { Chūō Jihō }\end{array}$ & $\begin{array}{l}\text { Headquar- } \\
\text { ters of the } \\
\text { Korean } \\
\text { League in } \\
\text { Japan }\end{array}$ & $\begin{array}{c}\text { August } \\
16,1947\end{array}$ & Tokyo & 20,000 & $\begin{array}{c}\text { Every } \\
\text { Other } \\
\text { Day }\end{array}$ & $\begin{array}{c}\text { Japanese } \\
\rightarrow \\
\text { Korean }\end{array}$ & $\begin{array}{l}\text { Bulletin of } \\
\text { the Head- } \\
\text { quarters of } \\
\text { the Korean } \\
\text { League in } \\
\text { Japan }\end{array}$ \\
\hline $\begin{array}{c}\text { Minsei } \\
\text { Jihō }\end{array}$ & $\begin{array}{l}\text { Headquar- } \\
\text { ters of the } \\
\text { Korean } \\
\text { Youth Alli- } \\
\text { ance in } \\
\text { Japan }\end{array}$ & $\begin{array}{c}\text { July } 5 \text {, } \\
1947\end{array}$ & Tokyo & 15,000 & $\begin{array}{c}\text { Every } \\
\text { Ten Days }\end{array}$ & Japanese & $\begin{array}{l}\text { Bulletin of } \\
\text { the Head- } \\
\text { quarters of } \\
\text { the Korean } \\
\text { Youth Alli- } \\
\text { ance in Japan }\end{array}$ \\
\hline $\begin{array}{c}\text { Chōren } \\
\text { Kanaga- } \\
\text { wa }\end{array}$ & $\begin{array}{c}\text { Kanagawa } \\
\text { Office of the } \\
\text { Korean } \\
\text { League in } \\
\text { Japan }\end{array}$ & & $\begin{array}{c}\text { Kanaga- } \\
\text { wa }\end{array}$ & & $\begin{array}{c}\text { Every } \\
\text { Ten Days }\end{array}$ & Japanese & $\begin{array}{c}\text { Bulletin of } \\
\text { the Kanaga- } \\
\text { wa Office of } \\
\text { the Korean } \\
\text { League in } \\
\text { Japan }\end{array}$ \\
\hline $\begin{array}{c}\text { Minjung } \\
\text { Sinmun } \\
\rightarrow \\
\text { Haebang } \\
\text { Sinmun }\end{array}$ & $\begin{array}{l}\text { Haebang } \\
\text { Sinmun } \\
\text { Company }\end{array}$ & $\begin{array}{c}\text { October } \\
10,1945\end{array}$ & Tokyo & $\begin{array}{c}30,000 \\
\rightarrow 50,000\end{array}$ & $\begin{array}{c}\text { Every } 10 \\
\text { Days }\end{array}$ & Korean & $\begin{array}{l}\text { Related to } \\
\text { the Korean } \\
\text { League in } \\
\text { Japan }\end{array}$ \\
\hline $\begin{array}{c}\text { Minshu } \\
\text { Shimbun } \\
\rightarrow \text { Min- } \\
\text { dan } \\
\text { Shimbun }\end{array}$ & $\begin{array}{l}\text { Headquar- } \\
\text { ters of the } \\
\text { Korean } \\
\text { Residents } \\
\text { Union in } \\
\text { Japan }\end{array}$ & & Tokyo & & Weekly & Japanese & $\begin{array}{l}\text { Bulletin of } \\
\text { the Korean } \\
\text { Residents } \\
\text { Union in } \\
\text { Japan }\end{array}$ \\
\hline $\begin{array}{l}\text { Chōsen } \\
\text { Shimbun }\end{array}$ & \begin{tabular}{|} 
Youth \\
Alliance for \\
the Promo- \\
tion of Ko- \\
rean Nation \\
Building
\end{tabular} & $\begin{array}{c}\text { March } \\
1946\end{array}$ & Tokyo & 12,000 & & Japanese & $\begin{array}{l}\text { Bulletin of } \\
\text { the Youth } \\
\text { Alliance for } \\
\text { the Promo- } \\
\text { tion of Kore- } \\
\text { an Nation } \\
\text { Building }\end{array}$ \\
\hline $\begin{array}{l}\text { Chōsen } \\
\text { Kokusai } \\
\text { Shimbun }\end{array}$ & $\begin{array}{l}\text { Chōsen } \\
\text { Kokusai } \\
\text { Shimbun } \\
\text { Company }\end{array}$ & $\begin{array}{c}\text { Febru- } \\
\text { ary } \\
1946\end{array}$ & Tokyo & & & Japanese & $\begin{array}{l}\text { Related to } \\
\text { the Youth } \\
\text { Alliance for } \\
\text { the Promo- } \\
\text { tion of Kore- } \\
\text { an Nation } \\
\text { Building and } \\
\text { the Alliance } \\
\text { for the Estab- } \\
\text { lishment of a } \\
\text { New Korea }\end{array}$ \\
\hline
\end{tabular}




\begin{tabular}{|c|c|c|c|c|c|c|c|}
\hline Title & Publisher & $\begin{array}{c}\text { Launch } \\
\text { Date }\end{array}$ & $\begin{array}{l}\text { Place of } \\
\text { Issue }\end{array}$ & Circulation & Frequency & Language & Notes \\
\hline $\begin{array}{l}\text { Chosŏn } \\
\text { Sinbo } \\
\rightarrow \text { Sin } \\
\text { Segye } \\
\text { Sinmun }\end{array}$ & $\begin{array}{l}\text { Chosŏn } \\
\text { Sinbo } \\
\text { Company } \\
\rightarrow \text { Sin } \\
\text { Segye } \\
\text { Sinmun } \\
\text { Company }\end{array}$ & $\begin{array}{l}\text { May } \\
1946\end{array}$ & Osaka & 75,000 & $\begin{array}{c}\text { Every Ten } \\
\text { Days }\end{array}$ & $\begin{array}{c}\text { Korean } \\
\text { and } \\
\text { Japanese }\end{array}$ & \\
\hline $\begin{array}{c}\text { Kokusai } \\
\text { Nichinichi } \\
\text { Shimbun }\end{array}$ & $\begin{array}{c}\text { Kokusai } \\
\text { Nichinichi } \\
\text { Shimbun } \\
\text { Company }\end{array}$ & & Tokyo & 27,000 & & Japanese & \\
\hline $\begin{array}{l}\text { Kokusai } \\
\text { Taimusu }\end{array}$ & $\begin{array}{l}\text { Chōsen } \\
\text { Kokusai } \\
\text { Taimusu } \\
\text { Company }\end{array}$ & $\begin{array}{c}\text { April 1, } \\
1946\end{array}$ & Tokyo & 100,000 & Daily & Japanese & \\
\hline
\end{tabular}

cupation's censorship. The censorship started immediately after the beginning of occupation. On September 3, 1945, the General Headquarters of the Supreme Commander for Allied Powers (GHQ/SCAP) established the Press, Pictorial and Broadcast (PPB) Division within its Civil Censorship Detachment. Until it was discontinued in November 1949, the division carried out the censorship of all Japanese domestic publications. From July 1948, the control of newspapers was changed to postpublication censorship. ${ }^{9}$ Most of the zainichi Korean newspapers and magazines I use in this article were published after November 1948 after the verdict of the Tokyo Trial was issued - and thus it is unlikely that those materials were subject to pre-publication censorship. Based on these sources, I will examine how zainichi Koreans viewed the Tokyo Trial. My research not only fills in the blank of existing studies on debates over war responsibility, which have focused only on the ideas and attitudes of the "Japanese" people, but also sheds new light on what Yoshida Yutaka characterized as "outstanding views on war responsibility

9 Taketoshi Yamamoto, An Analysis of the Media during the Occupation Period (占 領期メディア分析) (Tokyo: Hōsei University Press, 1996), 312. 
that were ignored in their time." ${ }^{10}$ I will discuss how zainichi Korean critiques raised crucial issues that Japanese historians would later bring to the fore in assessing the limits of the Tokyo Trial.

\section{The Beginning of the Tokyo Trial and the Zainichi Korean Press}

The Democratic National Front in Korea and Minjung Sinmun

The arrest of war criminal suspects by the Allied Occupation authorities started on September 11, 1945, immediately after the beginning of the occupation of Japan. General Douglas MacArthur ordered the establishment of the premises for the International Military Tribunal for the Far East on January 19, 1946. On April 29, Allied prosecutors issued indictments of twenty-eight individuals, and the trial opened on May 3. In southern Korea on May 22, a leftist political organization called the "Democratic National Front in Korea" issued a statement calling for the "strict punishment of Japanese war criminals." Democratic National Front required that "those who were directly responsible for suppressing and exploiting the Korean people through every single brutal way be punished severely, particularly those former GovernorsGeneral of Korea Minami Jirō and Koiso Kuniaki and other high-ranking [colonial] officials." The Democratic National Front also publicized an open call to General MacArthur and the Four-Nation Allied Committee on June 4, claiming: "The Korean people had suffered most acutely from the exploitation by Japanese imperialism. It is the general desire of the all Korean people that Emperor Hirohito, Minami Jirō, and Koiso Kuniaki be punished severely and that all other Japanese war criminals who commit-

10 Yoshida, "Debates over War Responsibility in Occupied Japan."

11 Tongnip Sinbo, May 23, 1946. 
ted crimes in Korea also be executed as soon as possible."12 It is worth noting that the Democratic National Front in Korea demanded the severe punishment of the Emperor, Minami, and Koiso. It seems that the Democratic National Front was the only organization in Korea that presented such a concrete set of demands regarding the Tokyo Trial.

In Japan, the same demands were also presented later by the Korean League in Japan (Chōren), which held close ties with the Democratic National Front in Korea. Chōren, the largest zainichi Korean organization, was founded on October 15, 1945, and Minjung Sinmun was one of the major zainichi Korean newspapers that represented Chören's political stance. On June 15, 1946, Minjung Sinmun published an editorial regarding the Tokyo Trial, titled "Investigate National Traitors at the War Crimes Tribunal!"13 The editorial praised the statement made by Chief Prosecutor Joseph Keenan who had articulated the responsibility of the Japanese leadership. The editorial also added that "the Japanese war criminals invaded our country, Korea, and also plotted to invade China, the Soviet Union and the Southern Pacific Islands." Given that the Tokyo Trial dealt chiefly with Japan's actions toward other nations after the nonaggression pact (Kellogg-Briand Pact) of 1928, the editorial's stance is very important; it broke the boundaries of this temporal framework, tracing Japan's aggression much earlier to the annexation of Korea in 1910. Moreover, what is most important about this editorial is that it linked the Tokyo Trial to the question of punishing Korean "colonial collaborators and national traitors" in Korea. Referring to the trials of those "who sold their countries to the enemy" in other countries, such as China's Chen Gongbo, Italy's Benito Mussolini, and Romania's Ion Antonescu, the editorial emphasized: "Our thirty million [Korean] brethren must not forget even in our sleep that there are unforgivable national traitors and colonial collaborators in our midst." The editorial also claimed that "we must work hard to expose and bring every single national traitor and co-

12 Chungoe Sinbo, June 5, 1946 and June 6, 1946.

13 Minjung Sinmun, June 15, 1946. 
lonial collaborator before the people's court as soon as possible" in order to "establish democratic government."14

As the Tokyo Trial opened its procedures, columns and articles started to appear in Minjung Sinmun and its successor Haebang Sinmun regarding various issues related to the trial, such as who the Japanese defendants were, who were on the defense team, and how Japanese society viewed the trial. For example, when Japanese defense lawyer Kiyose Ichirō caused controversies by describing the imperial propaganda of "eight corners of the world under one roof" (hakkō ichiu) - which served as the ideology to justify Japan's invasions - as an idea for "universal brotherhood" and "global fellowship," Haebang Sinmun immediately published its critique. ${ }^{15}$ Denouncing Kiyose's characterization of hakkō ichiu as "a call for global brotherhood," the editorial writer O Surin argued:

We know that this slogan and the ideas of a new order in East Asia were to justify the attempts of Japanese monopoly capitalists to turn the region into their backyard. Japanese militarist cliques the loyal dogs of these capitalists - inflicted savagery on entire East Asia, and we [Koreans] experienced this savagery on our own flesh and bones. ${ }^{16}$

The Question of War Responsibility in Chōsen Kokusai Shimbun and Chosŏn Sinbo

Chōren was not alone in paying attention to the war crimes trial in Japan. Newspapers managed by other zainichi Korean groups (non-Chōren groups) also watched the tribunal closely. One of the earliest opinion pieces that discussed the Tokyo Trial appeared in Chōsen Kokusai

14 Minjung Sinmun, June 15, 1946.

15 Haebang Sinmun, March 1, 1947.

16 Haebang Sinmun, March 1, 1947. 
Shimbun on March 1, 1946. ${ }^{17}$ The article, titled "A Thorough Investigation of the War Criminals Is the Foundation of Building a New Japan," praised the fairness of the trial organized by the Allied Powers, especially the attitude of the American attorneys who had been working hard for Japanese defendants. ${ }^{18}$ The article claimed that if Japanese attorneys volunteered to defend American war criminals, the Japanese would have called the attorneys "traitors" (hikokumin). Another article published on the same day referred to the trial of Captain Fukuhara Isao who had been charged with the brutal treatment of prisoners of war (POWs) at 17-B at Ōmuta, Fukuoka Prefecture. ${ }^{19}$ Fukuhara was put on trial for the maltreatment of an American corporal named Johnson. The article focused on the fact that Johnson had been locked in a guardhouse for talking with a Korean worker. Interestingly, the article then introduced a recollection of a different Korean worker, who said: "Because we, the Korean workers, were in similar conditions with American POWs, we sneaked under the watch of the Japanese guards to give tobacco and water to the Americans and also brought them food under the cover of darkness and console them.",20

On August 6, Chōsen Kokusai Shimbun also published an editorial titled "The Atrocities of the Japanese Army." The editorial raised a very important question regarding the Nanjing Massacre and the responsibility of Japanese soldiers. It argued:

17 Chōsen Kokusai Shimbun published numerous articles on rightist zainichi Korean organizations such as the Youth Alliance for the Promotion of Korean Nation Building (Chōsen Kenkoku Sokushin Seinen Dōmei) and the Alliance for the Establishment of a New Korea (Shin Chōsen Kensetsu Dōmei), which later participated in the Korean Residents Union in Japan (Zainihon Daikanminkoku Kyoryu Mindan) that supported the South Korean Syngman Rhee regime.

18 Chōsen Kokusai Shimbun, March 1, 1946.

19 Chōsen Kokusai Shimbun, March 1, 1946.

20 Chōsen Kokusai Shimbun, March 1, 1946. 
During the war, many Japanese soldiers who had just returned from the war front often talked about the war at closed-door parties and private conversations and boastfully recounted what they had done on the war front, such as the beheading of other nationals, plundering, and the raping of women. When they look back to their war experience now, do these soldiers still not have any remorse about the atrocities they committed?"21

At the same time, the editorial did not place responsibility solely on the shoulders of ordinary soldier, reminding the readers of the Imperial Army's dictum "Your superior's order is His Majesty's order." The editorial claimed that "we should not forget that today's misfortunes [were] products of the feudal system."22

Moreover, Chōsen Kokusai Shimbun also criticized Japan for having "not offered a single word of national apology or repentance to the people of China and Korea as well as of the Philippines and the South Sea Islands." In the same editorial, Chōsen Kokusai Shimbun condemned the Japanese for forgetting the magnanimity of Chiang Kai-shek who had called on the Chinese not to "repay violence with violence" and instead to protect the lives of the Japanese. The editorial concluded with sarcastic comments: "'Do not cast pearls before swine'; Let us hope that democratic Japan will not have to hear this phrase from the world."23

What is important about the editorial's emphasis on the responsibility of ordinary Japanese soldiers is that it could open up the possibility of questioning the responsibility of "Japanese people" in general - the next step following the prosecution of war criminals should be the pursuit of the responsibility of the people. In fact, editorials and critiques referring to the war responsibility of Japanese people and soldiers are unexpectedly few in number among the Chören-related zainichi Korean press. Consid-

21 Chōsen Kokusai Shimbun, August 6, 1946.

22 Chōsen Kokusai Shimbun, August 6, 1946.

23 Chōsen Kokusai Shimbun, August 6, 1946. 
ering this fact, Chōsen Kokusai Shimbun's attempt to draw attention to Japanese soldiers' atrocities in China deserves special attention. This is especially true because Chōsen Kokusai Shimbun not only discussed Japanese war crimes in China but also introduced a story about the war crimes trial in Yokohama to shed light on the war atrocities committed in Korea, the Philippines, and the South Sea Islands. Moreover, Chōsen Kokusai Shimbun had close ties with the leaders of zainichi Korean rightist groups, such as Pak Yŏl and Yi Kanghun who had connections with the Provisional Government of the Republic of Korea in China and its leader $\mathrm{Kim} \mathrm{Ku}$. It is possible that these political connections allowed Chōsen Kokusai Shimbun to pay close attention to Japanese atrocities in China.

In addition to Chōsen Kokusai Shimbun, Chosŏn Sinbo, a Koreanlanguage press founded in May 1946, deserves special mention. This newspaper had an important presence in zainichi Korean communities by offering abundant information about the lives of Korean residents and also presenting unique views on zainichi Korean movements. ${ }^{24}$ On December 26, 1947, Chosŏn Sinbo published an editorial titled "On the Tokyo War Crimes Trial" and praised that it was fair to put Minami Jirō and Koiso Kuniaki on trial as Class-A war crime suspects. ${ }^{25}$ In another editorial published on December 28, Chosŏn Sinbo targeted the claim made by Tōjo Hideki during the trial that the aim of the Greater East Asia CoProsperity Sphere had been for mutual coexistence and prosperity among the peoples of Asia. The editorial argued that the question of "whether they [Japanese leaders] had really aimed for liberating small and weak nations" was obvious when we understood how "the Korean people had suffered for thirty-six years" under Japanese rule. The editorial also continued: "The reason we raise questions about the past is precisely because they [defendants like Tōjō] are surprisingly so shameless that we cannot

24 On Chosŏn Sinbo, see Yŏng-hwan Chŏng, The Narrowing Path to Independence: A Five-Year History of Koreans in Japan (朝鮮独立への险路-在日朝鮮人の解放五年 史) (Tokyo: Hōsei University Press, 2013).

25 Chosŏn Sinbo, December 26, 1947. 
help but feel very angry.",26

It is clear from these articles that the opinion pieces published during the Tokyo Trial were overall supportive of the prosecution of Japanese war criminals and the position of prosecutors. Some pieces clearly pointed out the historical significance of the trial. For example, Chossen Shimbun, the bulletin of the Youth Alliance for the Promotion of Korean Nation Building (Chōsen Kenkoku Sokushin Seinen Dōmei, or Kensei), published an editorial titled "War Crimes and the International Military Tribunal for the Far East." 27 The editorial explained the historical significance of the Tokyo Trial by referring to the history of Napoleon's banishment to Saint Helena, tracing the evolution of the concept of "leadership responsibility" from its birth at the Treaty of Versailles out of the indictment of Kaiser Wilhelm II, to its establishment as a principle of international law at the Nuremberg Tribunal. The editorial then concluded with a comment on the urgent necessity that this principle be applied at the Tokyo Trial.

\section{Zainichi Korean Critiques of the Tokyo Trial Judgment}

Chōren's Criticism of the Verdict

Let us now examine how zainichi Korean organizations responded to the judgment of the Tokyo Trial. Among these, Chōren was the most critical of the judgment. Immediately following the announcement of the verdict of the tribunal, Chören issued a statement in the name of the central leadership. Taking issue with the fact that the former GovernorsGeneral of Korea Minami Jirō and Koiso Kuniaki had not received capital punishment, the Chōren leadership criticized the judgment as follows:

26 Chosŏn Sinbo, December 28, 1947.

27 Chōsen Shimbun, February 28, 1948. 
Because the definition of [war] crimes at this trial was built upon the legal basis of the non-aggression pact [Kellogg-Briand Pact of 1928], the Japanese aggression against our fatherland Korea the fact that Japan had deprived Korea of its independence, freedom, and culture until the very last bit under the brutal tyranny of the Japanese imperialist and militarist cliques and their accomplices - went completely unaddressed in the final indictment. ${ }^{28}$

The Choren leadership further addressed three critical points regarding the problem of the Tokyo Trial: 1) the need to bring the emperor to trial, without which it would never be possible to attain "true and sincere peace"; 2) the fact that the Japanese people were showing compassion to the war criminals, while in reality they should have taken the initiative and tried these criminals; and 3) the fact that there were war crime elements beyond the rigid classification of Class-A, B and C war crimes for example, the Chören leadership pointed out Yoshida Shigeru as such a case. Moreover, the Chōren leadership criticized the United States implicitly, claiming that it would not be beneficial for Japan if "only one of the Allied Nations play[ed] an excessive role" in the trial. This shows a critical shift in zainichi Koreans' attitude toward the Allied prosecution of Japanese war criminals - the overall support that Korean groups had previously expressed for the prosecutors at the early stage of the trial in 1946 disappeared. Rather, a critical stance toward the United States was now coming to the forefront as Koreans understood the trial verdict to have

28 Minsei Jiho, November 17, 1948. In fact, according to historian Udagawa Kōta, the Tokyo Trial prosecution possessed the information relating to Minami Jirō's time as the Governor-General of Korea - information such as about the Special Army Volunteer Soldier Edict and the sōshi-kaimei policy of forcing Koreans to adopt Japanese names. Yet, the interrogation of Minami focused mainly on the events surrounding the Manchurian Incident, while queries on his governor-generalship in Korea were few and far between. It was also the case for the interrogation of Koiso Kuniaki. See Kōta Udagawa, A Historical Study of the Tokyo Trial (東京裁判の史的 研究) (PhD diss., Hitotsubashi University, 2015), chapter 3. 
completely disregarded the question of Japan's colonization of Korea.

In particular, zainichi Koreans criticized the definition of Japan's “aggression" adopted in the Tokyo Trial, where prosecutors targeted Japanese war crimes committed between 1928 and 1945. Chören's bulletin Chōren Chūō Jihō addressed this question in its editorial as follows:

When one considers the history of Japanese imperialist aggression through the lens of Article 6 of the Potsdam Declaration [which declared the elimination of militarism in Japan], the trial's definition of Japan's overseas aggression must include the events of the early twentieth century, namely the Japan-Korea Protectorate Treaty of 1905. Otherwise, it would be impossible to accomplish a thorough investigation and elimination of the driving forces of Japanese imperialism. ${ }^{29}$

In other words, Chören tried to place the question of colonial responsibility - Japan's colonization of Korea - within the framework of "crimes against peace" and "responsibility for aggression." Thus, Chōren problematized the temporal framework (1928-1945) underlying the definition of Japanese "aggression" adopted by the Tokyo Trial.

At the same time, Chören also consistently articulated its position regarding the question of Japanese war responsibility. Chören argued that although Japanese people were not responsible for the war itself, it would have to be their duty to pursue their leaders' responsibility for the war. For example, in its discussion on the Tokyo Trial verdict, Chören's Kanagawa Prefecture office only denounced the two former GovernorsGeneral of Korea, Minami and Koiso, and their past colonial policies such as the implementation of the Volunteer Service System and the Japanization (kōminka) of Koreans. Chōren's Kanagawa Prefecture office also lamented the fact that Minami and Koiso had merely received life sen-

29 Chōren Chūō Jihō, November 11, 1948. 
tences. $^{30}$

Zainichi Korean Rightist Organizations' Views on the Tokyo Trial Verdict

Unlike Chōren, the two major zainichi Korean rightist groups, Korean Residents Union in Japan (Zainihon Daikanminkoku Kyoryü Mindan) and Kensei, took a positive stance toward the verdict of the Tokyo Trial. For example, in his statement published in Mindan's bulliten Minshu Shimbun on November 27, 1948, Mindan chairman Pak Yŏl praised the trial verdict and claimed:

If those who committed the crime of starting an aggressive war were ringleaders, the Japanese people were their accomplices. [...] Even those who did not support the war should be charged with assisting in murder unless they expressed out-and-out opposition. $^{31}$

Pak framed the responsibility of the Japanese people as that of being an "accomplice to murder." In his statement, Pak also warned of the persistent "residues of Japanese imperialism." He argued that "we should not conclude that the conviction of the twenty-five war criminals [had] brought a complete end to Japanese imperialism." Simultaneously, Pak also referred to how Koreans should respond to the trial verdict. He commented:

This judgment is just, and it will lead to a more civilized world in the future. For this very reason, we should sincerely reflect on what this verdict means, what it indicates. The whole [Korean] nation should now think about the responsibility we shoulder, rather than becoming stubborn and sentimental like left wing infantilists

30 Chōren Kanagawa, December 1, 1948.

31 Minshu Shimbun, November 27, 1948. 
[who just blame Japan]. In the face of the fair judgment of the supreme civilization, I hope that the whole nation will engage in self-reflection. ${ }^{32}$

One can see in his statement that Pak was critical of the way Chören ("Left wing infantilists") responded to the verdict of the Tokyo Trial. Unlike the Chōren leadership who focused on blaming Japanese militarist leaders for the past aggression, Pak called upon the Korean people to engage in certain self-criticism. In fact, previously Pak Yŏl had even expressed a negative view on anti-collaborator legislation proposed in the South Korean Interim Legislative Assembly in early 1947. Regarding this legislation, Pak rather argued for reflection on the "collective guilt of the thirty million" - that is, in his words, "the thirty million Koreans were all guilty." ${ }^{33}$ In other words, Pak had been reluctant to call for the punishment of colonial collaborators and war criminals. Like Pak, another Mindan-related newspaper Kokusai Nichinichi Shimbun also expressed a less critical stance toward the verdict of the Tokyo Trial. In its editorial published November 14, 1948, Kokusai Nichinichi Shimbun touched on the question of Japanese colonial rule but denied the need to pursue Japanese responsibility. The editorial claimed that Japanese colonial rule had "already become a thing of past history." 34

By contrast, another zainichi Korean rightist group Kensei maintained its critical position toward the question of Japanese colonial rule. Kensei's bulletin Chōsen Shimbun published an editorial on the trial verdict on December 3 and condemned what the Japanese colonial government had done in Korea during World War II, such as the implementation of the Volunteer Service System, the compulsory labor conscription, kōminka (Japanization) policy, and the sōshi-kaimei policy of forcing Koreans to

32 Minshu Shimbun, November 27, 1948.

33 Yŏl Pak, On New Revolution in Korea (新朝鮮革命論) (Tokyo: Chūgai Shuppan Kabushiki Kaisha, 1948).

34 Kokusai Nichinichi Shimbun, November 14, 1948. 
adopt Japanese names. The editorial also lamented the fact that Minami and Koiso had not been sentenced to death. Moreover, the editorial argued that the conscription of colonial subjects should be considered as "crimes against humanity." It claimed: "If the cruel treatment of Allied POWs [by Japanese officers] is considered the highest crime against humanity, so should be the Japanese policy of conscripting innocent Korean youths and sending them by force and by deceit to the battlefront to die." 35 In another article published on December 3, Chōsen Shimbun's editor Kim Chindu wrote that "Japanese imperialist and aggressive ideology [had] developed consistently since the Meiji era. Both their annexation of our country and their attempts to obtain the Liaodong Peninsula through a 99-year lease were the fruits of Japan's expansionist ideology." Kim also added:

The Japanese people should apologize, facing the whole world, for disturbing peace and endangering humanity. One way of expressing this repentance would be the abdication of the emperor. Yet, the emperor is touring his recently defeated country, allegedly offering his apology to the people of Japan. Before showing repentance to his people, the Japanese emperor must apologize to the people of the world. ${ }^{36}$

Zainichi Korean Media's Reaction to the South Korean Demand to Hand Over Minami and Koiso

The sentences imposed on the two former Governors-General of Korea, Minami and Koiso, evoked a sharp criticism from the South Korean government. Their sentences - life imprisonment - were apparently too lenient and not fully commensurate with their crimes in the view of the South Korean government. On November 19, 1948, the South Korean Foreign

35 Chōsen Shimbun, December 3, 1948.

36 Chōsen Shimbun, December 3, 1948. 
Minister Chang T'aeksang told foreign correspondents that "the Allied Powers lack[ed] the understanding of Japanese war crimes."37 According to Chang, "although it is natural to listen to the testimonies of Korean victims when the court tried war criminals related to Korea," the court reached the verdict "without any investigation on the victimization of Koreans." Chang also claimed: "It is no doubt that we have the right to demand the retrial by the Allied Powers of those Korea-related war criminals." ${ }^{38}$ Furthermore, Chang went as far as to call for the trial of some of Japanese war criminals by the South Korean court. He told the press that the South Korean government would try Minami, Koiso, and the former Commander of the Japanese Korean Army General Itagaki Seishirō for "crimes against humanity" as soon as the United Nations recognized South Korea. ${ }^{39}$

The zainichi Korean media immediately took up this issue. Sin Segye Sinmun, the successor to Chosón Sinbo, published an editorial expressing its support for Chang's claim. Referring to the fact that the Chinese Nationalist Government had held its own war crimes trials in Beijing in April 1946, Sin Segye Sinmun asserted that if the Tokyo Trial was not a "victor's justice" but a "tribunal in the name of civilization and humanity," Koreans, who were the "victim of crimes against humanity," had the right to participate in the trial. ${ }^{40}$ Sin Segye Sinmun also criticized the verdict for having "not charged or mentioned Japanese aggression in Korea" and lamented: "It is regrettable that [the trial] did not have the good faith to listen to even a single word of our [Koreans'] opinions."

The Japanese media such as Asahi Shimbun and Yomiuri Shimbun also reported, if briefly, Chang T'aeksang's statements. One opinion piece

37 Minju Ilbo, November 20, 1948.

38 Minju Ilbo, November 20, 1948.

39 Asahi Shimbun, November 23, 1948; Yomiuri Shimbun, November 30, 1948; Tonga Ilbo, November 30, 1948.

40 Sin Segye Sinmun, November 26, 1948.

41 Sin Segye Sinmun, November 26, 1948. 
published in the Japanese press Sekai Keizai Shimbun on November 24, 1948 responded to Chang's statements extensively. ${ }^{42}$ Interestingly, it characterized the South Korean government's demand for the retrial of Minami and Koiso as something that the Japanese would have to endure as the defeated. By stating that the South Korean government allegedly made claims to Tsushima Island and that "Koreans in Japan were violent against the Japanese," the opinion piece argued that "it [would] be unavoidable that as in the case of the emancipation of Japanese women, the liberation of Korea [would] encourage some excessive behavior" but the Japanese "should not resent Korea's lack of respect." It also continued: "We will not complain. Even if the world imposes a life sentence on us because of what our militarist leaders had done, we will accept it as a martyr to warmongers." 43

This opinion piece was not simply a critique of South Korea. In fact, it contained certain criticism of Japanese war criminals. The opinion piece understood that "because of what our militarist leaders had done," Koreans now dared to demand not only the cession of Tsushima Island but also the handover of Minami and Koiso. Moreover, the opinion piece even portrayed the Japanese as a victim of the liberation of Korea; it characterized the question of South Korea's demand to hand over the war criminals as a continuous victimization of the Japanese by Koreans' "excessive behavior" that had been triggered by the liberation of Korea.

Zainichi Korean newspaper Kokusai Taimusu lashed out at such a onesided view. In its editorial published on November 30, Kokusai Taimusu argued that Sekai Keizai Shimbun was distorting the meaning of South Korea's demand to hand over Minami and Koiso. ${ }^{44}$ Kokusai Taimusu emphasized that Minami and Koiso, as former Governors-General of Korea, were responsible for the "crimes against humanity" in Korea and therefore, "There is nothing wrong with South Korea's demand." Howev-

42 Sekai Keizai Shimbun, November 24, 1948.

43 Sekai Keizai Shimbun, November 24, 1948.

44 Kokusai Taimusu, November 30, 1948. 
er, it did not necessarily mean that Kokusai Taimusu was fully supportive of South Korea's demand. The editorial added:

The important thing is that such a demand is only justified based on the responsibility of representing the opinions of the Korean people. In this sense, there exist certain ambiguities as to whether South Korea's demand for handing over the two war criminals and its demand for Tsushima Island are justifiable. ${ }^{45}$

One can see that the editorial indicated certain reservations about the legitimacy of the South Korean government while expressing its support for the retrial of Minami and Koiso.

The South Korean government's proposition to try Minami, Koiso, and Itagaki on charges of "crimes against humanity" can be understood as its desperate attempt to problematize Japanese colonialism by appropriating the legal language of the Tokyo Trial and its definition of Japan's "aggression" (1928-1945). Yet, apparently, it became a vain attempt. There is no record that indicates the three war criminals were ever actually transferred to South Korea. Moreover, it is not clear how South Korea's demand was settled because there were no further news reports on this issue. In fact, the marginalization of Koreans that South Korean Foreign Minister Chang T'aeksang had problematized regarding the Tokyo Trial also continued in the San Francisco Peace Treaty signed in September 1951. The South Korean government was not invited - needless to say, neither was the North Korean government - to sign the peace treaty with Japan due to the strong opposition from the British and Japanese governments. ${ }^{46}$

45 Kokusai Taimusu, November 30, 1948.

46 Minsu Kim, "The Treaty of Peace with Japan and the Question of South Korean Participation,”(対日講和条約と韓国参加問題) Kokusai Seiji 131 (October 2002). 


\section{Conclusion}

Criticism presented by zainichi Korean newspapers and organizations regarding the Tokyo Trial show us the possibility of extending the pursuit of "war responsibility" to include "colonial responsibility." As I have discussed above, many of the editorial pieces disagreed with the verdict of the trial, arguing that the colonization of Korea was tantamount to aggression and thus constituted a "crime against peace." In other words, we can see how zainichi Koreans tried to link the pursuit of "war responsibility" to the question of colonial rule. Moreover, the zainichi Korean media also argued for judging wartime colonial policy, particularly, the Japanization of Koreans (kōminka policy), as a "crime against humanity." Such an argument was completely absent in Japanese discussions on war responsibility at that time. In this sense, the zainichi Korean media raised a critical voice demanding justice for Japanese crimes against "peace and humanity in Korea," the crimes that were ignored by the Allied Powers.

On the other hand, the question of whether the Japanese people in general, besides convicted Japanese militarist leaders, were responsible for the nation's aggressive war was not fully raised by the zainichi Korean media, particularly Chōren-related newspapers such as Minjung Sinmun and Haebang Sinmun that had a considerable influence among zainichi Korean communities. Like Japanese leftist intellectuals, Chören-related newspapers maintained a political stance that depicted the Japanese people as the victim of the militarist regime. Thus, like Japanese leftist groups, those newspapers were reluctant to raise the question of Japanese collective responsibility. However, there was a significant difference in their motives. Japanese leftists were reluctant, according to Japanese historian Yoshida Yutaka, to discuss Japanese collective responsibility because it might result in minimizing the responsibility of Japanese militarist leaders. ${ }^{47}$ On the contrary, Chōren's reluctance was apparently based on its strategic consideration. Chōren simply could not take a risk of turn-

47 Yoshida, "Debates over War Responsibility during the Occupation Period," 199. 
ing the entire Japanese people into its enemy while confronting the growing political suppression of their activities in Japan.

Yet, it is important to note that there was a certain frustration among zainichi Koreans toward Japanese reactions to the Tokyo Trial and their lack of self-reflection regarding the question of war responsibility. One zainichi Korean newspaper columnist wrote:

I often hear such words among the Japanese that: "We can't change the past, but from now on all East Asian peoples should get along together." Opportunists would greet such statements by raising both hands in approval.

However, is our relationship this simple? Isn't it rather similar to a situation where someone who has beaten you with their fists and knocked you down every time you tried to get up suddenly offers you a handshake without a word of apology? Those who did the beating could live with that, but the wounds of the beaten do not easily heal. The Chinese leader Chiang Kai-shek famously called at war's end "not to repay violence with violence," and we are not so narrow-minded as to recompense beating by beating. But, we cannot stand such an egoistic statement made by the Japanese. Or, maybe it is not worth criticizing the Japanese because they are such a racial group [jinshu] that even laments the death sentence imposed on Tōjō and other seven war criminals, saying "It's such a pity, such a pity!" They even tell us, "We are not people of a different race [like Americans]. We are all fellow East Asians!" 48

One can see a mixture of emotions in this column. The author expressed his irritation at the Japanese public opinion sympathetic toward Tōjō and his concern about Japanese attitudes toward war responsibility. He also criticized the Japanese who were expecting Koreans to take their

48 Bunkyō Shimbun, December 6, 1948. 
side against the "people of a different race" who had put Japanese leaders on trial. We can understand from this column why non-Chōren Korean groups often criticized the Japanese people's lack of self-reflection.

Yet, while those unique viewpoints existed at the time of the Tokyo Trial, the pursuit of Japan's colonial responsibility was never fully developed under the suppression of Korean social movements in Japan and the emergence of Cold War confrontation in East Asia. After the founding of the DPRK, the Japanese government and the Allied Occupation escalated their policing of Chören's political activities and even banned the display of the DPRK flag at Chōren's political rallies. Interestingly, Chōren's bulletin Chōren Chūō Jihō characterized such Japanese and Occupation's countermeasures as "crimes against peace":

The provocative and suppressive actions taken by the Japanese reactionary forces prohibiting the display of DPRK national flags correspond to the "aggression" and "crimes against peace" that the Tokyo Trial is currently adjudicating. ${ }^{49}$

As this critique epitomizes, political space for Choren's activities diminished significantly at the time of the end of the Tokyo Trial. In fact, Chōren became a target of the so-called "Organization Control Ordinance" on September 8, 1949 and was ordered by the Japanese government to disband its entire organization. As a result, zainichi Korean efforts of synthesizing "war responsibility" and "colonial responsibility" ended as an incomplete project.

In this article, I have examined how the zainichi Korean media and organizations responded to the Tokyo Trial and its pursuit of war responsibility. Their critiques of the Tokyo Trial often presented a critical insight from the perspective of anti-colonialism. Zainichi Koreans correctly questioned the absence of colonial responsibility in the pursuit of justice and war responsibility in the trial. In this sense, the problems of the Tokyo

49 Chōren Chūō Jihō, November 11, 1948. 
Trial that scholars started to "discover" in the 1970s had already been discussed by some zainichi Koreans in the late 1940s. A close examination of zainichi Korean debates over the trial opens up a new opportunity to understand what historian Yoshida Yutaka characterized as "outstanding views on war responsibility that were ignored in their time."50

\section{References}

1. Ara, Takashi. "A Trajectory of the Debates over the Tokyo Trial and War Responsibility”(東京裁判 - 戦争責任論の潮流). in An Introductory Study on the History of the Occupation of Japan (日本占領史研究序説). Tokyo: Kashiwa Shobō, 1994.

2. Akazawa, Shirō. "The Formation of the Symbolic Emperor System and War Responsibility Debates”(象徵天皇制の形成と戦争責任論). Rekishi Hyōron 315 (July 1976).

3. Arai, Shin'ichi. “On War Responsibility”(戦争責任について), in Studies on Contemporary History and the Textbook Trial (現代歴史学と教科書裁判). Tokyo: Aoki Shoten, 1973.

4. Arai, Shin'ichi. Asia in Contemporary History: Imperialism and Japan's War Responsibility (現代史におけるアジア：帝国主義と日本

の戦争責任). Tokyo: Aoki Shoten, 1977.

5. Awaya, Kentarō. “Shadows of the Tokyo Trial”(東京裁判の影). in On the Tokyo Trial (東京裁判論). Tokyo: Ōtsuki Shoten, 1989.

6. Chŏng, Yŏng-hwan. The Narrowing Path to Independence: A FiveYear History of Koreans in Japan (朝鮮独立への险路: 在日朝鮮人の解放五年史). Tokyo: Hōsei University Press, 2013.

7. Hayashi, Hirofumi. Class- $B$ and $C$ War Crimes Trials (BC級戦犯裁判). Tokyo: Iwanami Shoten, 2005.

8. Hayashi, Hirofumi. “'Comfort Women' Issues and War Crimes Trials”(“怎安婦” 問題と戦犯裁判). Gendai Shiso 35-10 (August 2007).

9. Hosoya, Chihiro and Nisuke Andō and Yasuaki Ōnuma eds. Interna-

50 Yoshida, "Debates over War Responsibility in Occupied Japan," 196. 
tional Symposium: Rethinking the Tokyo Trial (国際シンポジウム: 東京裁判を問う). Tokyo: Kōdansha, 1989.

10. Itagaki, Ryūta. "For the Theorization of Responsibility for Colonial Rule”(植民地支配責任を定立するために). in Unending Colonialism: Gender, Ethnicity/Nation, Race, Class (継続する植民地主義：ジェン ダー/民族/人種/階級). Tokyo: Seikyūsha, 2005.

11. Kim, Minsu. "The Treaty of Peace with Japan and the Question of South Korean Participation”(対日講和条約と韓国参加問題). Kokusai Seiji 131 (October 2002).

12. Kobayashi, Sōmei. Zainichi Korean Mediasphere: Newspaper Publication and Its Dynamics during the Occupation Period (在日朝鮮人のメディア空間: G H Q 占領期における新聞発行とそのダイナミズム). Tokyo: Fūkyōsha, 2007.

13. Miyamoto, Masaaki. "Studies on Korean Movements in Japan after World War II and the Prange Collection"(解放後在日朝鮮人史研究 とプランゲ文庫・覚書). in Media Publication and Culture during the Occupation Period (占領期の言論・出版と文化:〈プランゲ文 庫〉展・シンボジウムの記録). Waseda University and Ritsumeikan University, 2000.

14. Nagahara, Yōko. "What Is a Theory of 'Colonial Responsibility'?" (“植民地責任”論とは何か). in Theory of 'Colonial Responsibility': A Comparative History of Decolonization (“植民地責任”論：脱植民地 化の比較史). Tokyo: Aoki Shoten, 2009.

15. Totani, Yūma. "The Persecution of War Criminals and Judgement in the Tokyo Trial”(東京裁判における戦争犯罪訴追と判決). in Studies on Contemporary History and the Nanjing Incident (現代歴史学と南 京事件). Tokyo: Kashiwa Shobō, 2006.

16. Totani, Yūma. The Tokyo War Crimes Trial: The Pursuit of Justice in the Wake of World War II. Cambridge, Mass.: Harvard University Asia Center, 2008.

17. Ubukata, Naokichi. "Issues on the Tokyo Trial: 'Crimes against Humanities and the Statute of Limitations”(東京裁判をめぐる諸論 点: “人道に対する罪’と時効). Shisō 719 (May 1984). 
18. Udagawa, Kōta. A Historical Study of the Tokyo Trial (東京裁判の史 的研究). PhD diss., Hitotsubashi University, 2015.

19. Yamamoto, Taketoshi. An Analysis of the Media during the Occupation Period (占領期メディア分析). Tokyo: Hōsei University Press, 1996.

20. Yoshida, Yutaka. "Debates over War Responsibility during the Occupation Period”(占領期における戦争責任論). in Studies on Contemporary History and War Responsibility (現代歴史学と戦争責任). Tokyo: Aoki Shoten, 1997.

21. Yoshimi, Yoshiaki. "Japanese Popular Consciousness during the Occupation Period: Debates over War Responsibility”(占領期日本の 民衆意識-戦争責任論をめぐって). Shisō 811 (January 1992).

22. Yoshimi, Yoshiaki. Democracy from the Ashes: Grassroots Experience of the Occupation (焼跡からのデモクラシーー草の根の占領体 験). Tokyo: Iwanami Shoten, 2014. 
<Abstract>

\section{The Tokyo Trial and the Question of Colonial Responsibility: Zainichi Korean Reactions to Allied Justice in Occupied Japan}

This article examines how the zainichi Korean media and organizations responded to the Tokyo Trial and its pursuit of war responsibility. Their critiques of the Tokyo Trial often presented a critical insight from the perspective of anticolonialism. Zainichi Koreans correctly questioned the absence of colonial responsibility in the pursuit of justice and war responsibility in the trial. In this sense, the problems and limits of the Tokyo Trial that scholars started to "discover" in the 1970s had already been discussed by some zainichi Koreans in the late 1940s. By delving into previously under-explored historical sources, particularly the numerous newspapers published by zainichi Korean groups during the occupation period, this article demonstrates how zainichi Korean critics understood the limits of the Tokyo Trial beyond the binary of "victors' justice" and "the judgment of civilization."

Keywords: Tokyo War Trial; Korans in Japan; Colonial Responsibility; War Responsibility; U.S. Occupation of Japan; Crimes against Peace; Crimes against Humanity 


\section{〈국문초록〉}

\section{도쿄 전범재판과 식민책임 문제: 주일 점령군의 정의에 대한 재일조선인들의 반응}

정영환 (메이지가쿠인대학교 교양교육센터 교수)

본 연구는 제 2 차 세계대전 이후 도쿄 전범재판의 전쟁 책임 규명에 대한 재일 조선인 미디어 및 단체들의 대응을 다루었다. 도쿄 전범재판에 대한 그들의 비판 은 반식민주의 관점으로부터의 날카로운 통찰력을 보여주었다. 재일조선인들은 이 재판의 정의 및 전쟁 책임 규명에서 식민통치의 책임 문제가 결여되어 있음을 정확히 지적하였다. 지금까지 제대로 다루어지지 않은 사료들, 특히 미군정기에 다양한 재일조선인 그룹들이 간행한 신문들을 통하여 본 연구는 재일조선인 비평 가들이 “승자의 정의”와 “문명의 심판”이라는 도쿄 전범재판의 이원적 기준을 넘 어 그 한계를 어떻게 이해하고 있었는지 증명하였다.

주제어: 도쿄 전범재판, 재일조선인, 식민책임, 전쟁책임, 주일 미군정, 反평화 범죄, 反인권 범죄 
